\title{
Benzo[ghi]perylene Induces Morphological and Genotoxic Effects in Human Bronchial Cells Independently of The AhR Pathway
}

\section{Zelmy Castro-Gálvez}

Hospital Infantil de Mexico Federico Gomez

Montserrat Zaragoza-Ojeda

Hospital Infantil de Mexico Federico Gomez

Abrahan Hernández-Hernández

Hospital Infantil de Mexico Federico Gomez

Francisco Arenas-Huertero ( $\nabla$ farenashuertero@yahoo.com.mx )

Hospital Infantil de Mexico Federico Gomez https://orcid.org/0000-0002-8359-913X

\section{Research Article}

Keywords: Air pollution, PAH, NL-20 cells, genotoxicity, nuclear buds, benzo[ghi]perylene, AHR, TUNEL

Posted Date: February 15th, 2021

DOI: https://doi.org/10.21203/rs.3.rs-179899/v1

License: (a) (i) This work is licensed under a Creative Commons Attribution 4.0 International License. Read Full License 


\section{Abstract}

Polycyclic aromatic hydrocarbons (PAH) are organic compounds found in the contaminated atmosphere of Mexico City, where the PAH present with highest concentration is benzo[ghi]perylene [B[ghi]p]. We recently demonstrated that double-stranded breaks in DNA appear after $3 \mathrm{~h}$ of exposure, whereas cellular changes and activation of aryl hydrocarbon receptor (AHR) pathway occur after $48 \mathrm{~h}$ in bronchial cells under exposure to $\mathrm{B}[\mathrm{gh} i \mathrm{p}$, these findings have led us to explore if the AHR pathway participates in morphological changes and genotoxic effects due to B[ghi]p in human NL-20 bronchial cells. Cells of the $\mathrm{NL}-20$ human bronchial line were exposed to $\mathrm{B}[\mathrm{ghi}] \mathrm{]p}$ in the presence, or absence, of the AHR receptor antagonist, $\mathrm{CH}-223191$. Cell viability was quantified by the MTT assay, which revealed 76 and $66 \%$ at $6 \mathrm{~h}$ and 24h, respectively $(\mathrm{p}<0.001)$, regardless of the presence of $\mathrm{CH}-223191$. RT-qPCR showed an increase in the expression of the AHR and CYP1A1 cytochrome genes only after $24 \mathrm{~h}$ of exposure, and the expression was inhibited by $\mathrm{CH}-223191$. Genotoxicity assays revealed the presence of comets, nuclear buds (NB) and DNA fragmentation in cells exposed to B[ghi]p after $6 \mathrm{~h}$ and in cells exposed to $\mathrm{B}[\mathrm{ghi}] \mathrm{p}$ plus $\mathrm{CH}-223191$ at $24 \mathrm{~h}$. These results verify that $\mathrm{B}[\mathrm{gh} i \mathrm{j}$ induces morphological and genotoxic effects, and these effects are independent of the AHR pathway.

\section{Introduction}

The atmospheres of cities located at high latitudes - eg. Mexico City (MXCT) - contain complex mixtures of contaminants that include polycyclic aromatic hydrocarbons (PAH) (Amador-Muñoz et al. 2011) produced primarily by the incomplete combustion of fuels such as gasoline and diesel (Visciano and Perugini 2009). Automobiles, trucks and factories are the principal sources of PAH emissions in MXCT (SEDEM-GDF. 2012, RETC. 2019). In fact, Amador-Muñoz et al (2011) demonstrated that Benzo[ghi]perylene (B[ghi]p) was the most abundant PAH in the atmosphere of MXCT in the period between 1998-2002, and that it was contained in $\mathrm{PM}_{10}$. Later, Amador-Muñoz et al. (2013) showed that $\mathrm{B}[\mathrm{ghi}] \mathrm{p}$ is the most abundant PAH contained in $\mathrm{PM}_{2.5}$, mainly in the southwestern and downtown areas of MXCT.

$\mathrm{B}[\mathrm{ghi}] \mathrm{p}$ is a PAH of the type pericondensed. Its structure contains 6 rings and its molecular weight is 276 , but it has no bay or gulf regions (Marr et al. 1999). In 1983, the IARC classified B[ghi]p as noncarcinogenic in animals and humans, and the most recent evaluation (2010) established that B[ghi]p does not produce cancer by cutaneous application in mouse models; a finding supported by other studies that used the cutaneous injection technique (Müller 1968). Intrapulmonary application in a rat model failed to produce conclusive findings, since some tumors appeared, but the results were not reproducible (Deutsch-Wenzel et al. 1983, IARC. 1983). In vitro studies reported that B[ghi]p is mutagenic in the Salmonella typhimurium assay in presence of an exogenous metabolic system (rat fraction S9) (Platt and Grupe. 2005). Also, B[ghi]p correlated with dithiothreitol activity in an in vitro system designed to quantify the formation of reactive oxygen species (ROS) (Cho et al. 2005). In summary, few in vitro and in vivo studies have been conducted to evaluate the toxic properties of B[ghi]p. Recent work performed by our research group with cells of the human NL-20 bronchial line, showed that B[ghi]p after $48 \mathrm{~h}$ of 
exposure produced morphological changes in cells, consisting in the formation of small vesicles throughout the cytoplasm. Also, B[ghi]p showed these cellular effects: increased damage to the cell membrane, translocation of the aryl hydrocarbon receptor (AHR) to the nucleus, and the expression of genes that included the AHR receptor and cytochrome CYP4B1. Except for damage to the cell membrane and vesicle formation, these effects were reversed in presence of the $\mathrm{CH}-223191$ receptor antagonist which, in turn, increased oxidative stress, mainly of superoxide (Zaragoza-Ojeda et al. 2016). Very recently, Castro-Galvez et al. (2019) demonstrated that 3 h of exposure to $\mathrm{B}[\mathrm{ghi}] \mathrm{p}$ in this cell line, can induce $\mathbb{B} 2 \mathrm{AX}$ foci in the nuclei, despite of the increased expression of some DNA repair genes. The cell nuclei contained $\mathrm{B}[\mathrm{gh}] \mathrm{i}$ after $3 \mathrm{~h}$ of exposure and $\mathrm{B}[\mathrm{ghi}] \mathrm{p}$ remained there after $24 \mathrm{~h}$ of its washed out.

AHR is a ligand-dependent transcription factor that belongs to the basic helix-hoop-helix family (bHLH) Per/Arnt/Sim (PAS) and binds to a wide variety of exogenous compounds, including benzo[a]pyrene (B[a]p) and 2,3,7,8-tetrachlorodibenzo-p-dioxin (TCDD) (Opitz et al. 2011). AHR is found predominantly in the cytoplasm in a multiprotein complex that includes two hsp90 chaperone proteins ( $90-k D a$ heat shock proteins) that help maintain the conformation of the receptor, an AIP (auxiliary interacting protein) that stabilizes the interaction between the hsp90 and the receptor, and a p23 co-chaperone protein that stabilizes the intermediary ligand-AHR complex. In the presence of a ligand, the multiprotein complex becomes uncoupled and the AHR-PAH translocates to the nucleus, where it forms a heterodimer with ARNT (aryl hydrocarbon receptor nuclear translocator) (Larigot 2018, Opitz et al. 2011). The AHR-ARNT complex then binds to XRE (xenobiotic response elements) to induce the transcription of target genes that codify enzymes that participate in activation and detoxification; namely, phase I and phase II enzymes, such as CYPs and aldo-ketoreductases, AKR (among others), respectively, and proteins and enzymes that participate in the activation of cell cycle and cell adhesion, migration and differentiation. Once released from its ligand, AHR is degraded by the proteosome pathway in the nucleus (Roberts and Whitelaw 1999). As mentioned above, our group has described that $3 \mathrm{~h}$ of exposure to $\mathrm{B}[\mathrm{ghi}] \mathrm{p}$ in human bronchial cell line NL-20, can induce $\mathbb{B} 2 \mathrm{AX}$ foci in the nuclei, and the activation of AHR after $48 \mathrm{~h}$ of exposure. These findings led us to design the present study, in which we evaluated if morphological and genotoxic effects due to B[ghi]p in human NL-20 bronchial cells, depend on AHR pathway.

\section{Materials And Methods}

\section{Cultures of NL-20 cells}

The NL-20 cell line was obtained from the ATCC (CRL-2503). These are human epithelial bronchial cells immortalized from normal (i.e., non-tumorous) bronchi. Cells were cultured in HAM-F12 culture medium supplemented with $4 \%$ fetal bovine serum, $1 \%$ L-glutamine, $1 \%$ non-essential amino acids, $5 \mu \mathrm{g} / \mathrm{ml}$ of insulin, $10 \mathrm{ng} / \mathrm{ml}$ of epidermal growth factor, $1 \mu \mathrm{g} / \mathrm{ml}$ of transferrin, $500 \mathrm{ng} / \mathrm{ml}$ of hydrocortisone, 100 $\mu \mathrm{g} / \mathrm{ml}$ of streptomycin sulfate, and $100 \mu \mathrm{g} / \mathrm{ml}$ of Penicillin-G, under the following conditions: $37^{\circ} \mathrm{C}, 5 \%$ $\mathrm{CO}_{2}$ and relative humidity. They were detached in a solution of $0.05 \%$ trypsin and $0.01 \%$ versene for 10 
min at $37^{\circ} \mathrm{C}$ and were centrifuged at $1800 \mathrm{rpm}$ for $5 \mathrm{~min}$, and then counted in a hemocytometer before performing the following exposure assays to $\mathrm{B}[\mathrm{gh}] \mathrm{p}$.

\section{Exposure to B[ghi]p}

Previously, we performed assays at different times to exposure NL-20 cells to B[ghi]p and after did them, we decided to continue the study at $6 \mathrm{~h}$ and $24 \mathrm{~h}$ of exposure to B[ghi]p. The NL-20 cells were exposed following the experimental scheme: only medium; control vehicle (DMSO); $2.03 \mu \mathrm{M}$ of B[ghi]p and in the presence of $2.03 \mu \mathrm{M}$ of B[ghi]p $+10 \mu \mathrm{M}$ of $\mathrm{CH}-223191$ (antagonist of AHR receptor). All experiments were performed in triplicate, and results were obtained from three independent assays. The concentration of each compound was defined according to previous published assays (Zaragoza-Ojeda et al. 2016, Castro-Galvéz et al. 2019)

\section{Total RNA extraction}

Cells from the experimental scheme were lysed by adding $100 \mu \mathrm{L}$ of Trizol per well and stored at $-70^{\circ} \mathrm{C}$ until the samples from three biological triplicates were collected. In the next step of the extraction procedure, the cellular lysate was incubated for $5 \mathrm{~min}$ at room temperature, $60 \mu \mathrm{L}$ of cold chloroform were added, and the mixture was agitated in a vortex and left to ambient temperature for $10 \mathrm{~min}$. It was then centrifuged at $12,000 \mathrm{rpm}$ for $15 \mathrm{~min}$ at $4^{\circ} \mathrm{C}$ and the aqueous phase containing the RNA was recovered. This was transferred to a microtube with $150 \mu \mathrm{L}$ of cold isopropanol and $1 \mu \mathrm{L}$ of glycogen and incubated overnight at $-20^{\circ} \mathrm{C}$ to precipitate the largest quantity of total RNA possible. This was centrifuged at 12,000 $\mathrm{rpm}$ for $10 \mathrm{~min}$ at $4^{\circ} \mathrm{C}$. The supernatant was removed, and the RNA was washed twice with $300 \mu \mathrm{l}$ of ethanol $70 \%$, mixed gently and then centrifuged at $10,000 \mathrm{rpm}$ for $5 \mathrm{~min}$ at $4^{\circ} \mathrm{C}$. Finally, the alcohol was decanted, and the RNA was left to dry, afterwards it was re-suspended in $10 \mu \mathrm{L}$ water-RNases free. It was treated with DNase I ( $1 \mathrm{U}$ per $1 \mu \mathrm{g}$ of RNA) for $30 \mathrm{~min}$. The enzyme was inactivated with EDTA at $70^{\circ} \mathrm{C}$ for 10 min and the concentration and purity of the RNA was quantified in a NanoDrop. All samples had a 260/280 relation above 1.7 .

\section{cDNA synthesis}

cDNA synthesis was performed with $200 \mathrm{ng}$ of total RNA using the First Strand cDNA Synthesis kit (Thermo Scientific) in a thermocycler under the following conditions: at $37^{\circ} \mathrm{C}$ for $60 \mathrm{~min}$, at $70^{\circ} \mathrm{C}$ for 10 min, and at $22^{\circ} \mathrm{C}$ for $1 \mathrm{~min}$.

\section{Expression of the AHR, CYP1A1 and HOX-1 genes by RT- qPCR}

Gene expression was quantified in real-time with SYBR green as the principle fluorochrome and ROX as the passive reference colorant, as specified in the Maxima SYBER Green qPCR Master Mix Kit (Thermo Scientific). The specific primers for each gene were used (Table 1 ) and the reactions were carried out in a Stratagene Mx3005P thermocycler (Agilent) using the following program: at $95^{\circ} \mathrm{C}$ for $10 \mathrm{~min}, 40 \mathrm{cycles}$ at $95^{\circ} \mathrm{C}$ for 15 seconds at the melting temperature of each primer for $1 \mathrm{~min}$, and finalizing with one cycle at $95^{\circ} \mathrm{C}$ for $1 \mathrm{~min}$, at $58^{\circ} \mathrm{C}$ for $30 \mathrm{sec}$, and at $95^{\circ} \mathrm{C}$ for $30 \mathrm{sec}$. Expression levels were analyzed by applying 
the $2^{-\Delta \Delta C t}$ mathematical model (Pfaffl 2001; Livak and Schmittgen 2001) with GAPDH as the endogenous gene.

Table 1

Forward (F) and Reverse (R) sequences of the GAPDH, AHR, CYP1A1 and HOX-1 genes showing size in base pairs $(\mathrm{pb})$ of each amplified product and the optimal

TM for RT-qPCR.

\begin{tabular}{|c|c|c|c|c|}
\hline Genes & \multicolumn{2}{|c|}{ Oligonucleotides sequences } & Amplicon, size, bp & MT \\
\hline \multirow[t]{2}{*}{ GAPDH } & $\mathrm{F}$ & CGGAGTCAACGGATTTGGTC & \multirow[t]{2}{*}{96} & \multirow[t]{2}{*}{$58^{\circ} \mathrm{C}$} \\
\hline & $\mathrm{R}$ & ATGAAGGGGTCATTGATGGCA & & \\
\hline \multirow[t]{2}{*}{ AHR } & $\mathrm{F}$ & GCCGGTGCAGAAAACAGTAA & \multirow[t]{2}{*}{80} & \multirow[t]{2}{*}{$58^{\circ} \mathrm{C}$} \\
\hline & $\mathrm{R}$ & TAAGTCGGTCTCTATGCCGC & & \\
\hline \multirow[t]{2}{*}{ CYP1A1 } & $\mathrm{F}$ & ССТСААССТССТGСТАССТG & \multirow[t]{2}{*}{71} & \multirow[t]{2}{*}{$58^{\circ} \mathrm{C}$} \\
\hline & $\mathrm{R}$ & СTCCTGCAACGTGCTTATCAG & & \\
\hline \multirow[t]{2}{*}{ HOX-1 } & $\mathrm{F}$ & CAAAGTGCAAGATTCTGCCC & \multirow[t]{2}{*}{94} & \multirow[t]{2}{*}{$58^{\circ} \mathrm{C}$} \\
\hline & $\mathrm{R}$ & TGTAAGGACCCATCGGAGA & & \\
\hline
\end{tabular}

$6 \times 104$ cells were cultured $24 \mathrm{~h}$ before exposure onto coverslips pre-treated with poly-L-lysine [1:10] into $35 \mathrm{~mm}$ Petri dishes. At the end of the experimental scheme, the cells were washed with $1 \mathrm{~mL}$ of PBS and they were fixed with absolute methanol for $5 \mathrm{~min}$. The fixative was then removed, and the cells were washed 3 times with PBS for 5 min each. $1 \mathrm{~mL}$ of $0.2 \%$ Triton in PBS was used per sample for 30 min to permeabilize the cells. Subsequently, 3 washes were performed with $1 \mathrm{~mL}$ of PBS and background noise was blocked with $1 \mathrm{~mL}$ of $50 \mathrm{mM}$ glycine. Glycine was then removed and $100 \mu \mathrm{L}$ of $0.1 \%$ BSA in PBS supplemented with $10 \%$ goat serum was added for $1 \mathrm{~h}$. Samples were washed twice with $1 \mathrm{~mL}$ of PBS. $35 \mu \mathrm{L}$ of diluted primary antibody (AHR, ab 2770, 1:100) was added and incubated for 30 min at room temperature (RT) followed by incubation for $24 \mathrm{~h}$ at $4^{\circ} \mathrm{C}$ in a humid chamber. The next day, 3 washes of 10 min each were performed with $1 \mathrm{~mL}$ of $0.05 \%$ tween in PBS. $14 \mu \mathrm{L}$ of the following secondary antibody was added over 90 min: anti-mouse Alexa Flour 488 (1:200) (ab 150117) diluted in PBS as indicated. Subsequently, excess of antibody was removed with 3 washes of $0.05 \%$ Tween in PBS for 10 min each and 1 wash with PBS for 10 min. The samples were incubated with $100 \mu \mathrm{L}$ DAPI [10 $\mu \mathrm{g} / \mathrm{mL}]$ per sample for 5 min, mounted with mounting medium Vectashield and kept in dark at $4^{\circ} \mathrm{C}$ for further analysis with the fluorescence microscope Leica DMi8.

\section{MTT viability assay}

Following the protocol by Tolosa et al. (2015) for this assay, 15,000 cells were cultured per well in 96 -well plates $24 \mathrm{~h}$ before the experiment. Exposure times were $6 \mathrm{~h}$ and $24 \mathrm{~h}$. Cells were exposed to the experimental scheme conditions in triplicate, but 3 hours before ending each time, $20 \mu \mathrm{L}$ of MTT at a 
concentration of $5 \mathrm{mg} / \mathrm{mL}$ (in PBS) were added to each well. At the end of the exposure times, the medium was removed carefully before adding $100 \mu \mathrm{L}$ of acidic isopropanol to each well for 5 min under darkness. The amount of color was quantified in an ELISA plate at a wavelength of $540 \mathrm{~nm}$ as principal absorbance, and a wavelength of $620 \mathrm{~nm}$ to measure background absorbance. The percentage of reduced MTT was calculated using the absorbance obtained from the unexposed control-vehicle that was considered $100 \%$.

\section{Cell morphology}

Cells were cultured and were left to adhere on sterile coverslips before being exposed to the experimental scheme. At the end of the exposure times, they were fixed in absolute methanol for 5 min and left to dry before staining with $500 \mu \mathrm{L}$ of Giemsa for $10 \mathrm{~min}$. Next, they were washed to remove the excess colorant and left to dry. Finally, they were mounted with resin on slides and observed under an optical microscope at 100x. Photomicrographs were registered for any experimental scheme to reveal morphological changes.

\section{Nuclear electrophoresis analysis: COMET assay and nuclear buds}

At the end of the experimental scheme, cells were detached using trypsin and saline solution (1:9) in an incubator at $37^{\circ} \mathrm{C}$ for $15 \mathrm{~min}$. To concentrate, cells were centrifuged at $1800 \mathrm{rpm}$ for $5 \mathrm{~min}$, the supernatant was discarded, and cells were re-suspended in $100 \mu \mathrm{L}$ of complemented HAM-F12 culture medium. Next, $50 \mu \mathrm{L}$ were extracted and mixed with $90 \mu \mathrm{L}$ of low-fusion point agarose at $0.5 \%$ at $38^{\circ} \mathrm{C}$. Prior to this, agarose gels at $1 \%$ had been prepared in PBS on slides to empty the second layer of agarose with the cells, which was left to gel at $4^{\circ} \mathrm{C}$ for $7 \mathrm{~min}$. To obtain nuclei, the gels were left in lysis buffer (2.5 $\mathrm{M} \mathrm{NaCl}, 100 \mathrm{mM}$ EDTA, $10 \mathrm{mM}$ Tris, Triton 1\% X-100 and DMSO 10\%, pH 10) for $24 \mathrm{~h}$ at $4^{\circ} \mathrm{C}$.

In darkness, the gels were placed in a horizontal electrophoresis chamber with an alkaline buffer at $4^{\circ} \mathrm{C}$ (300 mMNaOH, $1 \mathrm{mM}$ EDTA pH 13) for $20 \mathrm{~min}$ to allow the DNA to unroll, and then for another $20 \mathrm{~min}$ at $25 \mathrm{~V}$ to starts the migration of the DNA fragments towards the anode. At that point, the gels were neutralized by 3 washings in neutralizing buffer $(0.4 \mathrm{M}$ Tris, $\mathrm{pH} 7.5)$ for $5 \mathrm{~min}$ each. The gels were then fixed in absolute ethanol at $4^{\circ} \mathrm{C}$ for 10 min and stained with $50 \mu \mathrm{L}$ of Gel Red (10\%) for analysis under fluorescence microscopy. The parameters considered to measure the damage in 100 nuclei per treatment were nuclei with comets and buds, expressed as the percentage of comets and of nuclei with buds.

\section{Detection of DNA fragmentation induced by B[ghi]p with the TUNEL assay}

To conduct this assay, we used the DeadEnd Colorimetric TUNEL System kit (Promega), exposing 45,000 cells from each experimental scheme to $\mathrm{B}[\mathrm{ghi}] \mathrm{p}$. After removing the culture medium, the cells were washed in $1 \mathrm{~mL}$ of saline solution to separate them with trypsin for $10 \mathrm{~min}$. To concentrate cells, they were centrifuged at $1800 \mathrm{rpm}$ for $5 \mathrm{~min}$. The solution was decanted and $100 \mu \mathrm{L}$ of saline solution were added for a wash with centrifugation at $1800 \mathrm{rpm}$ for $5 \mathrm{~min}$. The solution was decanted again, and cells 
were re-suspended in $100 \mu \mathrm{L}$ of saline solution. On previously prepared slides coated with silane $0.1 \%$, smears were taken for each experimental scheme and left to dry at $37^{\circ} \mathrm{C}$. These samples were then fixed with paraformaldehyde at $4 \%$ for 25 min and the presence of DNA fragmentation was revealed, following the instructions of the kit. The slides from three independent experiments were evaluated in an optical microscope, and the nuclei with DNA fragmentation were quantified in 100 cells and expressed as percentages of nuclei with DNA fragmentation.

\section{Statistical analysis}

The differences in the levels of expression of $A H R, C Y P 1 A 1$ and $H O X-1$, and the viability test were evaluated by ANOVA analysis. The presence of buds, the number of nuclei with DNA fragmentation, as determined by TUNEL, and the number of comets induced, were all evaluated by Ji-squared test. Differences were considered significant when the $p$ value was $<0.05$.

\section{Results}

The effect of B[ghi]p on cell viability is independent of the activation of the AHR pathway

The viability of cells exposed to B[ghi]p decreased $(p<0.001)$ to $76 \%$ and $66 \%$ at $6 \mathrm{~h}$ and $24 \mathrm{~h}$ of exposure, respectively (Fig. 1A). Both percentages of viability were above of the $50 \%$ inhibitory concentration $\left(\mathrm{Cl}_{50}\right)$. The effects of the reduction of viability due to exposure to $B[g h i] p$ were not reversed by the AHR antagonist $\mathrm{CH}-223191$ (Fig. 1A), this indicates that the reduction of the viability of the cells exposed to $\mathrm{B}[\mathrm{ghi}] \mathrm{p}$ after $6 \mathrm{~h}$ and $24 \mathrm{~h}$ of exposure in the presence of the $\mathrm{CH}-223191$ antagonist occurs independently of AHR pathway activation.

\section{The expression of AHR pathway is verified at 24 of exposure of B[ghi]p}

The transcriptional activation of the AHR pathway was evaluated. B[ghi]p

induces a significant increase $(\mathrm{p}<0.05)$ in the expression of the $A H R$ (Fig. 1B) and CYP1A1 (Fig. 1C) genes, but only after $24 \mathrm{~h}$ of exposure, compared to control vehicle (DMSO). However, the high expression of $A H R$ and $C Y P 1 A 1$ after $24 \mathrm{~h}$ of exposure returned to basal levels when cells were exposed to $\mathrm{B}[\mathrm{ghi}] \mathrm{p}$ plus the AHR antagonist $\mathrm{CH}-223191$ (Figs. 1B and 1C, respectively). These results proved that $\mathrm{B}[\mathrm{ghi}] \mathrm{p}$ at 24h activates the AHR pathway. Previously, Zaragoza-Ojeda et al. (2016) demonstrated that B[ghi]p induces oxidative stress at $48 \mathrm{~h}$ of exposure. Therefore, we decided to evaluate the expression of the HOX1 gene due to exposure to $B[g h i] p$. Figure 1D shows an increase of expression of this gene $(p<0.05)$, in $6 \mathrm{~h}$ and $24 \mathrm{~h}$ of exposure, which indirectly indicates the induction of oxidative stress.

\section{Translocation of the AHR receptor after B[ghi]p exposure}

Immunocytochemistry illustrates that, after $6 \mathrm{~h}$ of exposure to $\mathrm{B}[\mathrm{ghi}] \mathrm{p}$, there is a weak signal of protein (Figs. $2 \mathrm{H}$ and $2 \mathrm{~K}$ ), and it remains mainly in cytoplasm (Fig. $3 \mathrm{I}$ ), also in presence of the antagonist $\mathrm{CH}$ - 
223191 (Figs. 2I and 2L). At 24h of exposure to B[ghi]p, the AHR protein is translocated mainly to the nucleus (Figs. 2T and 2W, cyan color in merge, Fig. 2W) and in presence of AHR antagonist CH223191, the protein is weakly detected (Figs. $2 \mathrm{U}$ and $2 \mathrm{X}$ ). These results verify $\mathrm{B}[$ ghi]p activates the pathway because the protein is translocated to the nucleus

\section{Morphological changes in cells exposed to B[ghi]p}

To characterize the morphological changes produced by B[ghi]p, at $6 \mathrm{~h}$ and $24 \mathrm{~h}$, the analysis of photomicrographs shows the presence of intracytoplasmic vesicles (IVs) in NL-20 cells exposed to both $\mathrm{B}[$ ghi]p (Figs. 3C and 3G) and in $\mathrm{B}$ [ghi]p plus antagonist $\mathrm{CH}-223191$ (Figs. 3D and 3H). At 6h, there is not $A H R$ gene expression (Fig. 1B) and cells exposed to B[ghi]p alone have IVs (Fig. $3 \mathrm{C}$ ): it proves this morphological modification is independent of any interaction of $\mathrm{B}[\mathrm{ghi}] \mathrm{p}$ to any receptor. The presence of IVs also remains after 24 of exposure to $\mathrm{B}$ [ghi]p (Fig. 3G), even in presence of the antagonist $\mathrm{CH}-223191$ (Fig. 3H). The IVs are formed independent of the AHR pathway.

\section{Genotoxic effects due to B[ghi]p}

To evaluate the genotoxic effects that $\mathrm{B}[$ ghi]p might have on the nuclei of bronchial cells, a COMET assay, quantification of nuclear buds (NB), and DNA fragmentation determined by the TUNEL assay were performed. COMET analysis showed low, non-significant differences in formation of comets induced by $\mathrm{B}[\mathrm{ghi}] \mathrm{p}$ between $6 \mathrm{~h}$ and $24 \mathrm{~h}$ of exposure, even in presence of the antagonist $\mathrm{CH}-223191$ ( $p>0.05)$ (Fig. 4A), so we did not do any other measurements (v.g. tail moment of the comet/width of the tail). Regardless, the number of comets induced were significantly higher $(\mathrm{p}<0.05)$ in cells exposed to $\mathrm{B}[\mathrm{gh}] \mathrm{p}$ compared to those observed in the negative control and medium (Fig. 4A). In contrast, there was a significant increase of NB in cells exposed to both conditions: $B[g h i] p$ alone and in presence of the AHR antagonist $\mathrm{CH}-223191$ at $6 \mathrm{~h}$ and $24 \mathrm{~h}(\mathrm{p}<0.05)$ (Fig. 4B). These results show that induction of comets and NB occurs independently of the AHR receptor pathway.

Finally, B[ghi]p induced DNA fragmentation in $70 \%$ of the exposed cells, compared to only $3 \%$ of controls $(p<0.05)$ at $6 \mathrm{~h}$ of exposure. $\mathrm{CH}-223191$ cannot lower the DNA fragmentation as it is observed in controls (Fig. 4C). However, at 24h, there was reduced percentage of cells with DNA fragmentation (18\%). The presence of the $\mathrm{CH}-223191$ (Fig. 4C), reduced cells with DNA fragmentation at $15 \%$, but these differences were not significant $(p>0.05)$. This confirm that DNA fragmentation is not dependent of the AHR pathway.

\section{Discussion}

\section{Cell viability and morphological changes}

Although the AHR pathway was not activated at $6 \mathrm{~h}$ of exposure to B[ghi]p, surprising observations were performed and included the decrease in cell viability accompanied by morphological changes in the NL20 bronchial cells. These results are similar with those of a study conducted with A549 pulmonary 
adenocarcinoma cells exposed to $2 \mu \mathrm{M}$ of $\mathrm{B}[$ ghi]p for $14 \mathrm{~h}$, which reported $68 \%$ viability (Genies et al. 2016). Those findings indicate that $\mathrm{B}[\mathrm{ghi}] \mathrm{p}$ is cytotoxic and, perhaps, that the integrity of the mitochondria of the exposed cells is compromised by a decrease in the amount of metabolically-active cells, accompanied by greater oxidative stress. The particulate material (PM) and fuel emissions associated with the PAH have been shown to interfere with the function of mitochondria in both electron transport and the transitory permeability of the aperture of the mitochondrial pore (Xia et al. 2007). The mitochondrial toxic effect of $\mathrm{B}[\mathrm{ghi}] \mathrm{p}$ is currently under study in our laboratory.

$\mathrm{B}[\mathrm{gh}] \mathrm{p}$ induces changes in the cytoplasm that include increasing the number of vesicles at $48 \mathrm{~h}$ of exposure to different concentrations. Vesicle formation is not inhibited by the AHR antagonist (ZaragozaOjeda et al. 2016), suggesting that cell changes caused by exposure to B[ghi]p is produced by an AHRindependent pathway. Our study demonstrated that the AHR pathway was not activated at $6 \mathrm{~h}$ of exposure, but cells have vesicles characteristic of longer exposure (24h), this result also verify the AHRindependent pathway involved. Other research has shown that exposure of A549 cells to PM 10 generates the appearance of what are called cytoplasmic inclusions, with 2-3 mM alin diameter (Mazzarella et al. 2007), a finding also reported by Ferecatu et al. (2010), but with $\mathrm{PM}_{2.5}$. It may be related to the onset of cell death by apoptosis, as reported by Johnson et al. (2000), who induced DNA damage with staurosporine in the presence of caspase inhibitors. Or IVs can represent an alteration of another via, v.g. vesicular traffic, a finding that is currently being explored in our laboratory

\section{The genotoxic effects of B[ghi]p after short exposure times occur independently of the AHR pathway}

Previously, our group demonstrated that exposing NL-20 bronchial cells to B[ghi]p for $48 \mathrm{~h}$, induces morphological damage and the transcriptional activation of the AHR pathway (Zaragoza-Ojeda et al. 2016). However, the question of whether cell damage and AHR pathway activation can begin after only short exposure times to $\mathrm{B}[\mathrm{ghi}] \mathrm{p}$ remained unresolved. In an effort to clarify this, the present study evaluated genotoxic damage and AHR pathway activation at $6 \mathrm{~h}$ and $24 \mathrm{~h}$ of exposure to B[ghi]p, at concentrations lower than those reported earlier by our group. The most significant result of this study was that the AHR pathway was not activated at $6 \mathrm{~h}$ of exposure, although cytotoxic and genotoxic damage and morphological changes to the human NL-20 bronchial cells did occur.

In cells of the WB-T344 epithelial line, the complex mixtures derived from the urban particles did activate the AHR receptor, and that activation contributes to the carcinogenic properties of these mixtures (Andrysik et al. 2011). There is, however, controversy in this regard. Depending on cell type, activation of this pathway can produce different effects, including the fact that in LNCaP prostate carcinoma cells, AHR pathway activation plays an important role in the non-genotoxic effects of $\mathrm{B}[\mathrm{gh}] \mathrm{i}$, such as inhibition of the cell cycle (Hrubá et al. 2011). It is important to note that studies with other cell lines (eg. H4IIE hepatoma), have shown that this hydrocarbon is a weak AHR inducer compared to the agonist, TCDD, since $10 \mu \mathrm{M}$ of $\mathrm{B}[\mathrm{ghi}] \mathrm{p}$ is required to achieve the same effect that is induced with only $100 \mathrm{pM}$ of TCDD after $6 \mathrm{~h}$ of exposure. However, the mutagenesis or genotoxicity processes and potential AHR activation are properties of the PAH that can occur independently (Machala et al. 2001), as has been shown using 
benzo[ $k$ fluoranthene, a potent AHR inducer, but weak genotoxic agent, that produces low levels of adducts in the DNA of alveolar epithelial cells of A549 adenocarcinoma (Líbalová et al. 2014).

The increase of RNAm of the CYP1A1 and AHR genes is a classic marker of the AHR pathway activation that reflects the activation of the metabolism of phase I xenobiotics (Pan et al. 2013). The present study, however, did not detect any increase in the transcription of the AHR and CYP1A1 genes at $6 \mathrm{~h}$ of exposure of the $\mathrm{NL}-20$ cells to $\mathrm{B}[\mathrm{ghi}] \mathrm{p}$. This indicates that longer exposure times to $\mathrm{B}[\mathrm{gh}] \mathrm{p}$ are required to activate the pathway, as was demonstrated at $24 \mathrm{~h}$ of exposure, with the resulting transcriptional increase of $A H R$ and CYP1A1.

\section{Genotoxic damage induced by B[ghi]p in cells of the NL-20 bronchial line}

The PAH with bay or gulf regions have the potential to induce DNA damage; one example is B[a]p (MacLeod et al. 1991). The main pathway for producing toxic and genotoxic damage is activation of the AHR receptor (Andrysik et al. 2011, Libalova et al. 2014). However, the short exposure time to B[ghi]p used in the present study revealed cell damage without AHR pathway activation. This is similar with reports that observed DNA damage due to the B[a]p metabolite, benzo[a]pyrene-trans-7,8-dihydrodiol-9-10epoxide (BPDE), which can bind directly to DNA independently of the metabolic process of the AHR pathway (Hockley et al. 2007).

To evaluate the possible genotoxic effect of $\mathrm{B}[\mathrm{ghi}] \mathrm{p}$, the present study utilized, among other techniques, the COMET assay (Merk and Speit 1999). Because B[ghi]p is a PAH without bay or gulf regions, it cannot generate dihydrodiol epoxides; hence, it likely causes oxidative damage of the bases, similar to what has been suggested for anthanthrene (Desler et al. 2009). This may explain the low number of small-tailed comets reported by Platt and cols. (2008) in V79 hamster lung fibroblast cells, even at a high concentration, $50 \mu \mathrm{M}$ of $\mathrm{B}[\mathrm{ghi}] \mathrm{p}$. This damage did not increase with metabolic activation. The frequency of comets induced by exposure to $\mathrm{B}[\mathrm{gh}] \mathrm{j}$. is low even at concentrations 10 times higher than the one used in the present study $(2.03 \mu \mathrm{M})$, as reported by Rodríguez-Romero et al. (2012) in human peripheral lymphocytes, where exposure to this hydrocarbon produced around $9 \%$ of comets, a figure that increased to almost $28 \%$ with $\mathrm{S} 9$ metabolic activation. The low frequency of comets induced by B[ghi]p is due to the comet assay is essentially a method of detecting single-strand breaks (Kawaguchi et al. 2010, Heuser et al. 2002), and B[ghi]p, according to results reported by Castro-Galvez et al. (2019), induces doublestrand breaks that were proved by the results of TUNEL assay in this study, that will be discussed below.

However, upon analyzing the nuclei after unicellular electrophoresis of the exposed cells, we observed a significant percentage of NB at $6 \mathrm{~h}$ of exposure. Some researchers consider that these abnormalities of the nuclei are zones of amplified DNA that the cells removed during the $S$ phase of the cell cycle (Fenech 2002). It is thought that almost all these NB originate from acentric, telomeric or interstitial fragments, perhaps representing DNA that is trapped in the nuclear membrane and remains there after nuclear division or, perhaps, excess DNA that is excluded from the nucleus but stays tightly-connected to it through a stem of nucleoplasmic material. These events have been associated with chromosomal instability (Lindberg et al. 2007, Fenech et al. 2011). Meanwhile, by marking all the chromosomes with 
fluorescent probes and evaluating the genotoxic effect of zidovudine on bone marrow mesenchymal cells, Dutra et al. (2010) demonstrated that less than $50 \%$ of the NB contain positive signs for one or two chromosomes, although over $50 \%$ had no marking signal, and some even showed the presence of a centromere. This suggests that the NB may contain fragments of some chromosome, a hallmark of genetic instability and do not necessarily represent only amplification zones.

In addition, NB are sensitive biomarkers that indicate exposure to diverse compounds (Nersesyan. 2005). Examples of this are the PAH mixtures to which coke oven operators are exposed, which showed a 3.5fold increase in the amount of NB compared to a control group. This means that they can be used as indicators of chromosomal damage to biomonitor workers exposed to PAH, and that their frequency can be correlated with exposure time (Duan et al. 2009). While the mechanism of NB formation in this system is unknown, the fact that their appearance was observed after short exposure times during which, the AHR-mediated pathway was not activated, suggests that NB can function as early markers of exposure to $\mathrm{B}[\mathrm{ghi}] \mathrm{p}$.

\section{DNA fragmentation}

The results of exposure to $\mathrm{B}[\mathrm{a}] \mathrm{p}$ by Tung et al. (2014) and $\mathrm{B}[\mathrm{gh} i \mathrm{i}$ found in this study demonstrate induction of DNA fragmentation. The $B[a] p$ has a bay region that identifies it as a carcinogenic with a high capacity to generate DNA fragmentation (Ramesh et al. 2004). The B[ghi]p in contrast, has no bay or gulf region but, according to our results, is also capable of inducing DNA fragmentation (Castro-Galvez et al. 2019). Another molecule that has no such regions is anthanthrene but, according to the results of Desler et al. (2009), it can induce DNA fragmentation in cell lines regardless of distinct gain- and loss-offunction phenotypes in the DNA repair mechanisms. Using in vitro DNA, Platt et al. (2008) showed that the $\mathrm{K}$ region of $\mathrm{B}[\mathrm{gh}] \mathrm{p}$ can produce 3,4-oxides responsible for DNA interaction with a weak binding property, such that no adducts are produced. This $\mathrm{K}$ region, which is present in other PAH as well including $\mathrm{B}[\mathrm{gh}] \mathrm{]}$ - preferentially generates deoxyguanosine (Rojas and Alexandrov 1986) and deoxyadenosine (Nair et al. 1991). In this regard, Desler et al. (2009) propose that the PAH with no bay or gulf regions are generators of oxidative stress, and that it is through this pathway that they cause oxidative damage in nitrogenous bases of DNA such as 8-oxo-dG. These PAH with $\mathrm{K}$ regions are very weak tumor initiators compared to the PAH that have bay or gulf regions (Berry et al. 1977).

DNA fragmentation can support the fact that $\mathrm{B}[\mathrm{gh}] \mathrm{i}$ do not have bay or gulf regions and its oxidative effects can induce breaks of DNA double-strand. This was verified by Castro-Galvez et al. (2016) previously since this PAH can induce as earlier breaks of double-strand DNA at $3 \mathrm{~h}$ by $\nabla \mathrm{H} 2 \mathrm{AX}$ foci in the nuclei, and at $6 \mathrm{~h}$ by TUNEL positive cells. Probably, at $24 \mathrm{~h}$, DNA repair enzymes could repair, and it can explain the reduction of TUNEL positive nucleus.

\section{Conclusions}

This work demonstrated that short-term exposure to $\mathrm{B}[\mathrm{gh} / \mathrm{i}$ p functions as a cytotoxic and genotoxic agent whose effect is independent of the AHR-mediated pathway. B[ghi]p can induce morphological changes in 
cells, reduces their viability, and cause comets, formation of NB and DNA fragmentation: markers of genotoxicity. This finding opens up a broad field of study since B[ghi]p seems to affect cells in two distinct ways: independently of the AHR-pathway at short exposure times, and at $24 \mathrm{~h}$. This raises the following question: $¿$ what is the overall effect of prolonged exposure to $B[g h i] p$ on the structure of the genome of bronchial cells? Research into these important issues is underway in our laboratory with the expectation that in the near future we will be able to provide some answers to these key questions.

\section{Declarations}

\section{Declarations}

Not applicable

\section{Ethics approval and consent to participate}

Not applicable

\section{Consent for publication}

Not applicable

\section{Availability of data and materials}

Not applicable

\section{Competing interests}

The authors declare that they have no competing interests

\section{Funding}

The authors would like to thank the Fondos Federales of Dirección de Investigación of Hospital Infantil de México Federico Gómez for financial support through the projects HIM/2016/006/ SSA 1257 and $\mathrm{HIM} / 2019 / 028$

\section{Authors' contributions}

Zelmy Castro-Gálvez, perform assays of morphological changes, immunocytochemistry, cytotoxicity and genotoxicity. Also statistical analysis. Montserrat Zaragoza-Ojeda, perform the analysis of genes expression. Abrahan Hernández-Hernández, critical review to draft. Francisco Arenas-Huertero drafted the first version of the manuscript and finish the scope of the study.

\section{Acknowledgements}


This article constitutes a partial fulfillment of the requirements of Posgrado en Ciencias Biológicas. The doctoral student Zelmy Castro Gálvez acknowledges the scholarship and financial support, which is granting by Consejo Nacional de Ciencia y Tecnología CONACyT with CVU 441122 and No. scholar 270151 and the Universidad Nacional Autónoma de México, UNAM.

\section{References}

1. Amador-Muñoz O, Villalobos-Pietrini R, Miranda J, Vera-Ávila LE (2011) Organic

2. compounds of $\mathrm{PM}_{2.5}$ in Mexico Valley: spatial and temporal patterns, behavior and sources. Sci Tot Environ 409:1453-1465.

3. https://doi.org/10.1016/j.scritotenv.2010.11.026

4. Amador-Muñoz O, Bazán-Torija S, Villa-Ferreira SA, Villalobos-Pietrini R, Bravo-Cabrera JL, MuniveColín Z, Hernández-Mena L, Saldarriaga-Noreña H, Murillo-Tovar MA (2013) Opposing seasonal trends for polycyclic aromatic hydrocarbons and PM10: Health risk and sources in southwest Mexico City. Atmos Res 122: 199-212.

5. https://doi.org/10.1016/j.atmosres.2012.10.003

6. Andrysík Z, Vondrácek J, Marvanová S, Ciganek M, Neca J, Pencíková K, Mahadeva B, Topink J, Baird W, Kozubík A, Machala M (2011) Activation of the aryl hydrocarbon receptor is the major toxic mode of action organ organic extract of a reference urban dust particulate matter mixture: The role of polycyclic aromatic hydrocarbons. Mut Res 714: 53- 62

7. doi: 10.1016/j.mrfmmm.2011.06.011

8. Berry D L, Slaga T J, Viaje A, Wilson N M, DiGiovanni J, Juchau M R, Selkirk JK (1997) Effect of trichloropropene oxide on the ability of polyaromatic hydrocarbons and their "K-region" oxides to initiate skin tumors in mice and to bind to DNA in vitro. J Nat Cancer Inst 58: 1051-1055

9. DOI: $10.1093 / \mathrm{jnci} / 58.4 .1051$

10. Castro-Gálvez Zelmy, Garrido-Armas Mónika, Palacios-Arreola Margarita Isabel,

11. Torres-Flores Ulises, Rivera-Torruco Guadalupe, Valle-Rios Ricardo, Amador- Muñoz Omar, Hernández-Hernández Abrahan, Arenas-Huertero Francisco $\quad$ (2019) Cytotoxic and genotoxic effects of Benzo[ghi]perylene on the human bronchial cell line NL-20. Toxicol In Vitro 61:104645

12. doi: $10.1016 /$ j.tiv. 2019.104645

13. Cho AK, Sioutas C, Miguel AH, Kumagai Y, Schmitz DA, Singh M (2005) Redox activity of airborne particulate matter at different sites in the Los Angeles Basin. Environ Res 99, 40-47

14. doi: 10.1016/j.envres.2005.01.003

15. Desler C, Johannessen C, Rasmussen L J (2009) Repair of DNA damage induced by anthanthrene, a polycyclic aromatic hydrocarbon (PAH) without bay or fjord regions. ChemicoBiological Int 177: 212-217

16. doi: 10.1016/j.cbi.2008.10.056 
17. Deutsch-Wenzel R, Brune H., Grimmer G, Dettbarn G, Misfeld O (1983) Experimental Studies in Rat Lungs on the Carcinogenicity and Dose-Response Relationships of Eight Frequently Occurring Environmental Polycyclic Aromatic Hydrocarbons. J Nat Cancer Inst 71: 539-544

18. Dutra A, Pak E, Wincovitch S, John K, Poirier M C, Olivero O A (2010) Nuclear bud formation: a novel manifestation of Zidovudine genotoxicity. Cit Genome Res 128: 105-110

19. doi: $10.1159 / 000298794$

20. Duan H, Leng S, Pan Z, Dai Y, Niu Y, Huang C, Bin P, Wang Y, Liu Q, Chen W, Z Zheng Y 2009 Biomarkers measured by cytokinesis-block micronucleus cytome assay for evaluating genetic damages induced by polycyclic aromatic hydrocarbons. Mut Res 677: 93-99

21. doi: $10.1016 /$ j.mrgentox.2009.06.002

22. Fenech M, Kirsch-Volders M, Natarajan A T, Surralles J, Crott J W, Parry J, Norppa H, Eastmond D A, Tucker J D, Thomas P (2011) Molecular mechanism of micronucleus, nucleoplasmic bridge and nuclear bud formation in mammalian and human cells. Mutagenesis 1: 125-132

23. doi: $10.1093 /$ mutage/geq052

24. Fenech M (2002) Biomarkers of genetic damage for cancer epidemiology. Toxicology 181-182: 411-416.

25. doi: $10.1016 / \mathrm{s} 0300-483 \times(02) 00480-8$

26. Ferecatu I, Borot M C, Bossard C, Leroux M, Boggetto N, Marano F, Baeza-Squiban A, Andreau K (2010) Polycyclic aromatic hydrocarbon components contribute to the mitochondria-antiapoptotic effect of fine particulate matter on human bronchial epithelial cells via the aryl hydrocarbon receptor. Part Fiber Toxicol 7: $\quad$ 1-14

27. doi: $10.1186 / 1743-8977-7-18$

28. Genies C, Jullien A, Lefebvre E, Revol M, Maitre A, Douki T (2016) Inhibition of the formation of benzo[a]pyrene adducts to DNA in A549 lung cells exposed to mixtures of polycyclic aromatic hydrocarbons. Toxicol In Vitro 35: 1-10

29. doi: 10.1016/j.tiv.2016.05.006

30. Hockley S L, Arlt V M, Brewer D, Poele R, Workman P, Giddings I, Phillips D H (2007) AHR- and DNA-Damage-Mediated Gene Expression Responses Induced by Benzo(a)pyrene in Human Cell Lines. Chem Res Toxicol 20: 1797-1810

31. doi: $10.1021 / \mathrm{tx} 700252 \mathrm{n}$

32. Hrubá E, Vondráček J, Líbalová H, Topinka J, Bryja V, Souček K, Machala M (2011) Gene expression changes in human prostate carcinoma cells exposed to genotoxic and nongenotoxic aryl hydrocarbon receptor ligands. Toxicol Lett 206:178-188

33. doi: 10.1016/j.toxlet.2011.07.011

34. IARC. Polynuclear aromatic compounds (1983) Part 1: Chemical, environmental and experimental data. Monographs on the Evaluation of the Carcinogenic Risk of Chemicals to Humans, vol. 32. IARC Press, Lyon 
35. IARC. Some non-heterocyclic polycyclic aromatic hydrocarbons and some related exposures (2010) Monographs on the Evaluation of the Carcinogenic Risk of Chemicals to Humans, 92. IARC Press, Lyon.

36. Johnson V L, Ko S C W, Holmstrom T H, Eriksson J E, Chow S C (2000) Effector caspases are dispensable for the early nuclear morphological changes during chemical-induced apoptosis. $J$ Cell Science 113: 2941-2953

37. Larigot L, Juricek L, Dairou J, Coumoul X (2018) AhR signaling pathways and regulatory functions. Biochim Open. 2018 7:1-9.

38. doi: 10.1016/j.biopen.2018.05.001

39. Líbalová H, Krčková S, Uhlírová K, Milcová A, Schmuczerová J, Ciganek M, Kléma J, Machala M, Šrám R J, Topinka J (2014) Genotoxicity but not the AhR-mediated activity of PAHs is inhibited by other components of complex mixtures of ambient air pollutants. Toxicol Lett 225: 350-357

40. doi: 10.1016/j.toxlet.2014.01.028

41. Livak KJ, Schmittgen TD (2001) Analysis of relative gene expression data using real- time quantitative PCR and the 2(-DD C(T)) Method. Methods 25: 402-408

42. doi: $10.1006 /$ meth.2001.1262

43. Lindberg H K, Wan X, Jarventaus H, Falck G C, Norppa H, Fenech M (2007) Origin of nuclear buds and micronuclei in normal and folate-deprived human lymphocytes. Mutation Research 617: $33-45$

44. doi: 10.1016/j.mrfmmm.2006.12.002

45. Machala M, Vondráček J, Bláha L, Ciganek M, Neča J (2001) Aryl hydrocarbon receptor-mediated activity of mutagenic polycyclic aromatic hydrocarbons determined using in vitro reporter gene assay. Mut Res 49: 49-62

46. doi: 10.1016/s1383-5718(01)00240-6

47. MacLeod M C, Daylong A, Adair G, Humphrey R M (1991) Differences in the rate of DNA adduct removal and the efficiency of mutagenesis for two benzo(a)pyrene diol epoxides in $\mathrm{CHO}$ cells. Mut Res 261:267-79

48. doi: 10.1016/0165-1218(91)90042-k

49. Marr LC, Kirchstetter TW, Harley RA, Miguel AH, Hering SV, Hammond SK (1999) Characterization of polycyclic aromatic hydrocarbons in motor vehicles fuels and exhaust emissions. Environ Science Tech 33: 3091-3099

50. Mazzarella G, Ferraraccio F, Prati M V, Annunziata S, Bianco A, Mezzogiorno A, Liguori G, Angelillo I F, Cazzola M (2007) Effects of diesel exhaust particles on human lung epithelial cells: an in vitro study. Resp Medicine 101: 1155- 1162

51. doi: 10.1038/s41419-018-1111-y

52. Merk O, Speit G (1999) Detection of crosslinks with the comet assay in relationship to genotoxicity and cytotoxicity. Environ Mol Mut 33:167-172 
53. doi: 10.1002/(sici)1098-2280(1999)33:2<167::aid-em9>3.0.co;2-d

54. Müller E (1968) Carcinogenic substances in water and soils. Studies on the carcinogenic properties of 1, 12-benzoperylene. Arch Hyg Sci 152: 23-36

55. Nair R V, Gill R D, Nettikumara A N, Baer-Dubowska W, Cortez C, Harvey R G, DiGiovanni J (1991) Characterization of covalently modified deoxyribonucleosides formed from dibenz[a,j]anthracene in primary cultures of mouse keratinocytes. Chem Res Toxicol 4:115-122

56. DOI: $10.1021 / \mathrm{tx} 00019 \mathrm{a} 016$

57. Nersesyan A K (2005) Nuclear buds in exfoliated human cells. Mut Res 588: 64-68

58. DOI: 10.1016/j.mrgentox.2005.06.010

59. Opitz CA, Litzenburger UM, Sahm F, Ott M, Tritschler I, Trump S, Schumacher T,

60. Jestaedt L, Schrenk D, Weller M, Jugold M, Guillemin GJ, Miller CL, Lutz C, Radlwimmer B, Lehmann I, von Deimling A, Wick W, Platten M (2011) An endogenous tumour-promoting ligand of the human aryl hydrocarbon receptor. Nature 478: 197-203

61. doi: 10.1038/nature10491

62. Pan S, Li D, Zhao L, Schenkman J B, Rusling J F (2013) Genotoxicity-Related Chemistry of Human Metabolites of Benzo[ghi]perylene (B[ghi]P) Investigated using Electro-Optical Arrays and DNA/MicrosomeBiocolloid Reactors with LC-MS/MS. Chem Res Toxicol 26: 1229-1239

63. doi: $10.1021 / \mathrm{tx} 400147 \mathrm{c}$

64. Pfaffl MW (2001) A new mathematical model for relative quantification in real-time $\quad$ RT-PCR. Nucl Acids Res 29: e45

65. doi: 10.1093/nar/29.9.e45

66. Platt KL, Grupe S (2005) Microsomal biotransformation of benzo[ghi]perylene, a mutagenic polycyclic aromatic hydrocarbon without a classic bay region. Chem Res Tox 18: 700-710

67. doi: $10.1021 / \mathrm{tx} 049698 \mathrm{a}$

68. Platt K. L, Aderhold S, Kulpe K, Fickler M (2008) Unexpected DNA damage caused by polycyclic aromatic hydrocarbons under standarg laboratory conditions. Mut Res 650: 96-103

69. doi: 10.1016/j.mrgentox.2007.09.011

70. Ramesh A, Walker S A, Hood D B, Guillen M D, Scheneider K, Weyand E H (2004) Bioavailability and risk assessment of orally ingested polycyclic aromatic hydrocarbons Int $\mathrm{J}$ Toxicol 23: 301-333

71. doi: $10.1080 / 10915810490517063$

72. RETC (Registro de Emisiones y Transferencia de Contaminantes) (2019) Ciudad de México. Available in: https://www.gob.mx/semarnat/acciones-y-programas/registro-de-emisiones-ytransferencia-de-contaminantes-retc. Accessed Sep 122020

73. Roberts B J, Whitelaw (1999) Degradation of the basic Helix-Loop-Helix/Per-ARNT 
74. Sim homology domain dioxin receptor via the ubiquitin/proteasome pathway. J Biol Chem 274: 36351-36356

75. doi: $10.1074 / j b c .274 .51 .36351$

76. Rodríguez-Romero M I, Gómez-Arroyo S, Villalobos-Pietrini R, Martínez-Valenzuela C, Cortés-Eslava J, Calderón-Ezquerro M. del Carmen, García-Martínez R, Arenas-Huertero F, Calderón-Segura M E (2012) Evaluation of 8-hydroxy-2Х- deoxyguanosine (8-OHdG) adduct levels and DNA strand breaks in human peripheral blood lymphocytes exposed in vitro to polycyclic aromatic hydrocarbons with or without animal metabolic activation. Toxicol Mech Methods 22: 170-183

77. doi: $10.3109 / 15376516.2011 .623330$

78. Rojas M, Alexandrov K (1986) In vivo formation and persistence of DNA and protein adducts in mouse and rat skin exposed to ( \pm )benzo[a]pyrene-4,5-oxide. Carcinogenesis 2: $235-240$

79. doi: $10.1093 /$ carcin/7.2.235

80. Satomi Kawaguchi, Takanori Nakamura, Ayumi Yamamoto, Gisho Honda, Yu F Sasaki (2010) Is the comet assay a sensitive procedure for detecting genotoxicity?

81. J Nucleic Acids 2010:541050

82. doi: $10.4061 / 2010 / 541050$

83. SEDEMA-GDF (Secretaría de Medio Ambiente del Gobierno del Distrito Federal) (2012) Inventario de Emisiones Contaminantes y de Efecto Invernadero de la Zona Metropolitana del Valle de México 2012. Available in: http://www.aire.df.gob.mx/default.php?opc=Z6Bhnml=\&dc=Zg==. Accessed Sep 142020.

84. Tolosa L, Donato MT, Gómez-Lechón MJ (2015) General Cytotoxicity Assessment by Means of the MTT Assay. Methods Mol Biol 1250: 333-48

85. doi: 10.1007/978-1-4939-2074-7_26.

86. Tung E, Philbrook N, Belanger C, Ansaria S, Winn L (2014) Benzo[a]pyrene increases DNA double strand break repair in vitro andin vivo: A possible mechanism for benzo[a]pyrene-induced toxicity. Mut Res 760: 64- 69

87. doi: 10.1016/j.mrgentox.2013.12.003

88. Vanina D Heuser, Juliana da Silva, Heinz-Jörn Moriske, Johnny F Dias, Maria Lúcia Yoneama, Thales R O de Freitas. (2002) Genotoxicity biomonitoring in regions exposed to vehicle emissions using the comet assay and the micronucleus test in native rodent Ctenomys minutus. Environ Mol Mutagen 40: 227-35.

89. doi: 10.1002/em.10115.

90. Visciano P and Perugini M (2009). Polycyclic aromatic hydrocarbons toxicity in

91. animals and humans. In: Haines PA, and Hendrickson MD (Eds.) Polycyclic aromatic hydrocarbons: Pollution, health effects and chemistry. Pp. 52-66.

92. Xia T, Kovochich M, Nel A E (2007) Impairment of mitocondrial function by particulate matter (PM) and their toxic components: implications for PM- induced cardiovascular and lung 
93. doi: $10.2741 / 2142$

94. Zaragoza-Ojeda M, Eguía-Aguilar P, Perezpeña-Díazconti M, Arenas-Huertero F (2016)

Benzo[ghi]perylene activates the AHR pathway to exert biological effects on the NL-20 human bronchial cell line. Toxicol Lett. 2016 256:64-76

95. doi: 10.1016/j.toxlet.2016.05.023.

\section{Figures}

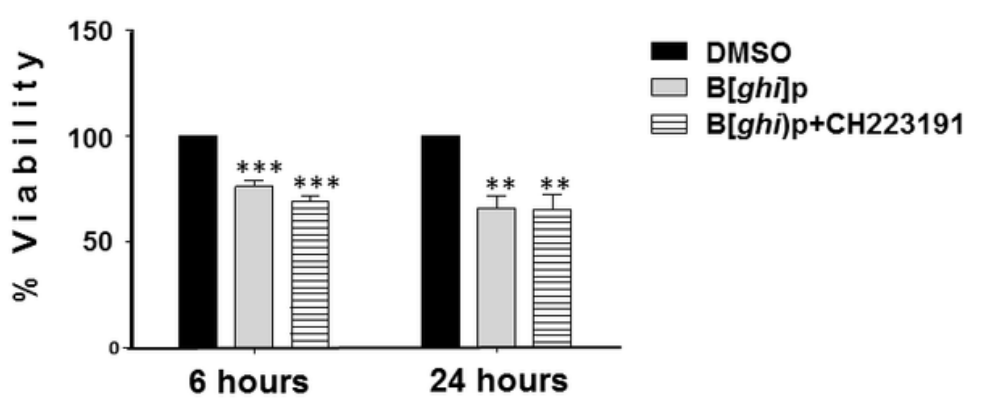

A MTT
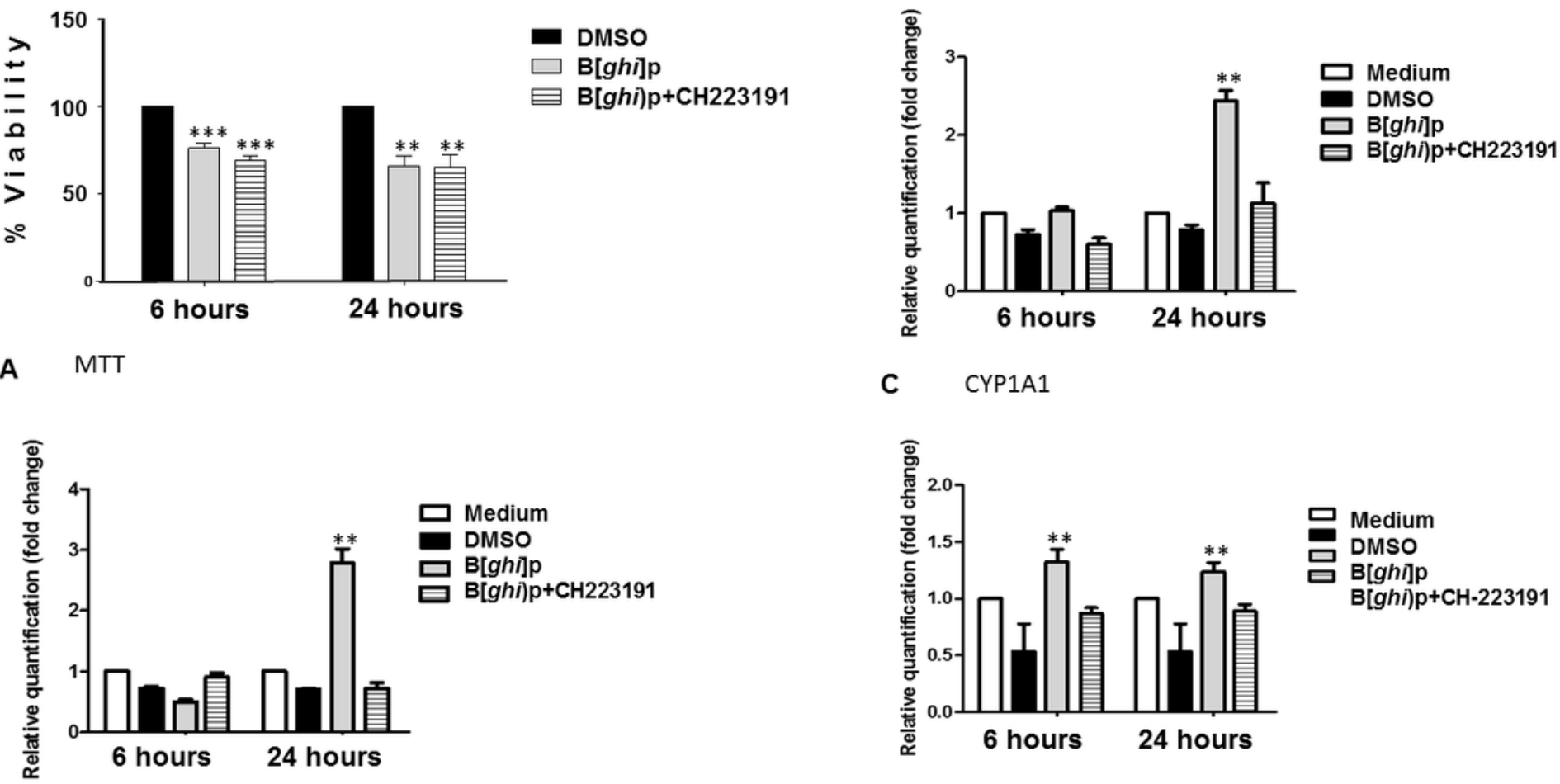

C CYP1A1

B $\quad$ AHR

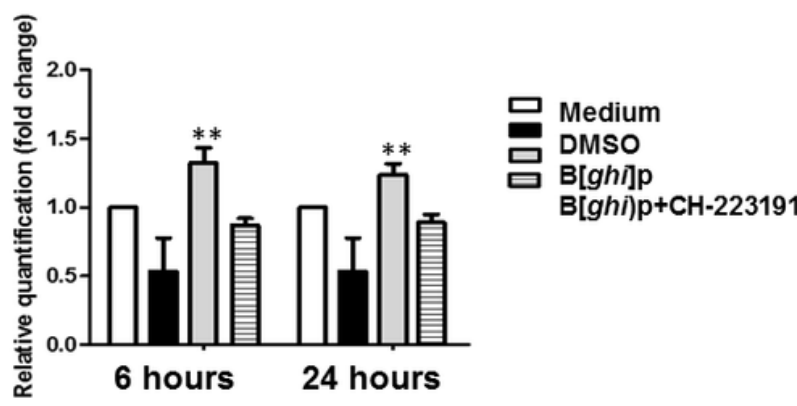

D HOX-1

Figure 1

A. MTT Viability assay of viability of MTT NL-20 cells exposed to DMSO (black bars), B[ghi]p (grey bars) and $\mathrm{B}$ [ghi]p $+\mathrm{CH}-223191$ (dashed bars), by 6 hours and 24 hours. Each bar shows the mean + standard error. Results are from three independent experiments. ${ }^{* \star *} p<0.001,{ }^{* \star} p<0.01$. B. Gene expression of AHR (B), CYP1A1 (C) and HOX-1 (D) quantified by qPCR-RT of NL-20 cells exposed to medium (white bars), DMSO (black bars), B[ghi]p (grey bars), B[ghi]p $+\mathrm{CH}-223191$ (dashed bars) by 6 hours and 24 hours. Each bar shows the mean + standard error. Results are from three independent experiments. ${ }^{\star \star} p<0.01$. 


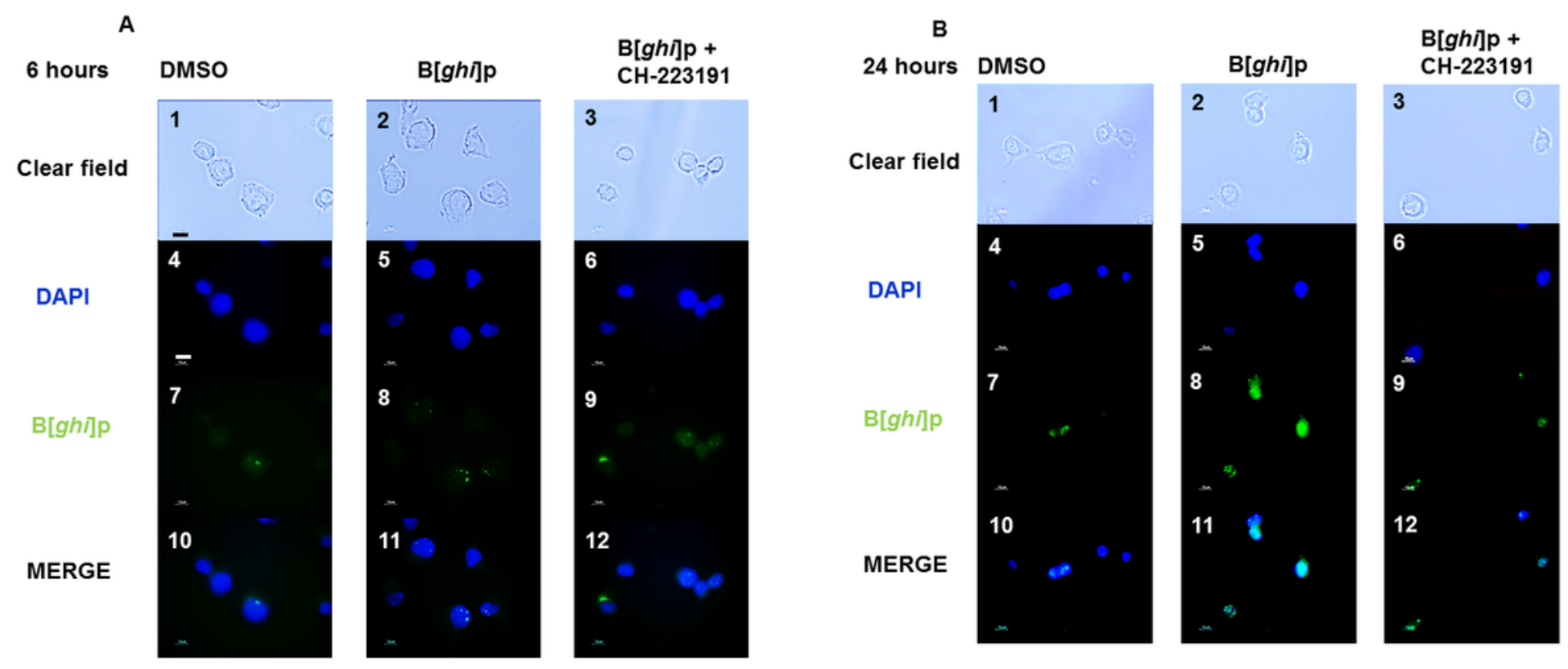

Figure 2

A. Immunocytochemistry of AHR in cells exposed to 6 hours. 1, 2 and 3, micrographies in bright field. 4, 5 and 6 nuclei staining by DAPI and observed by fluorescence. 7, 8 and 9 immunostaining against AHR. 10, 11 and 12 merge images from 4 and 7, 5 and 8 , and 6 and 9, respectively. B. Immunocytochemistry of AHR in cells exposed to 24 hours. 1, 2 and 3, micrographies in bright field. 4, 5 and 6 nuclei staining by DAPI and observed by fluorescence. 7, 8 and 9 immunostaining against AHR. 10, 11 and 12 Merge images from 4 and 7, 5 and 8 , and 6 and 9, respectively. Black and white bar of scale is equivalent to 10 $\mu \mathrm{m}$.

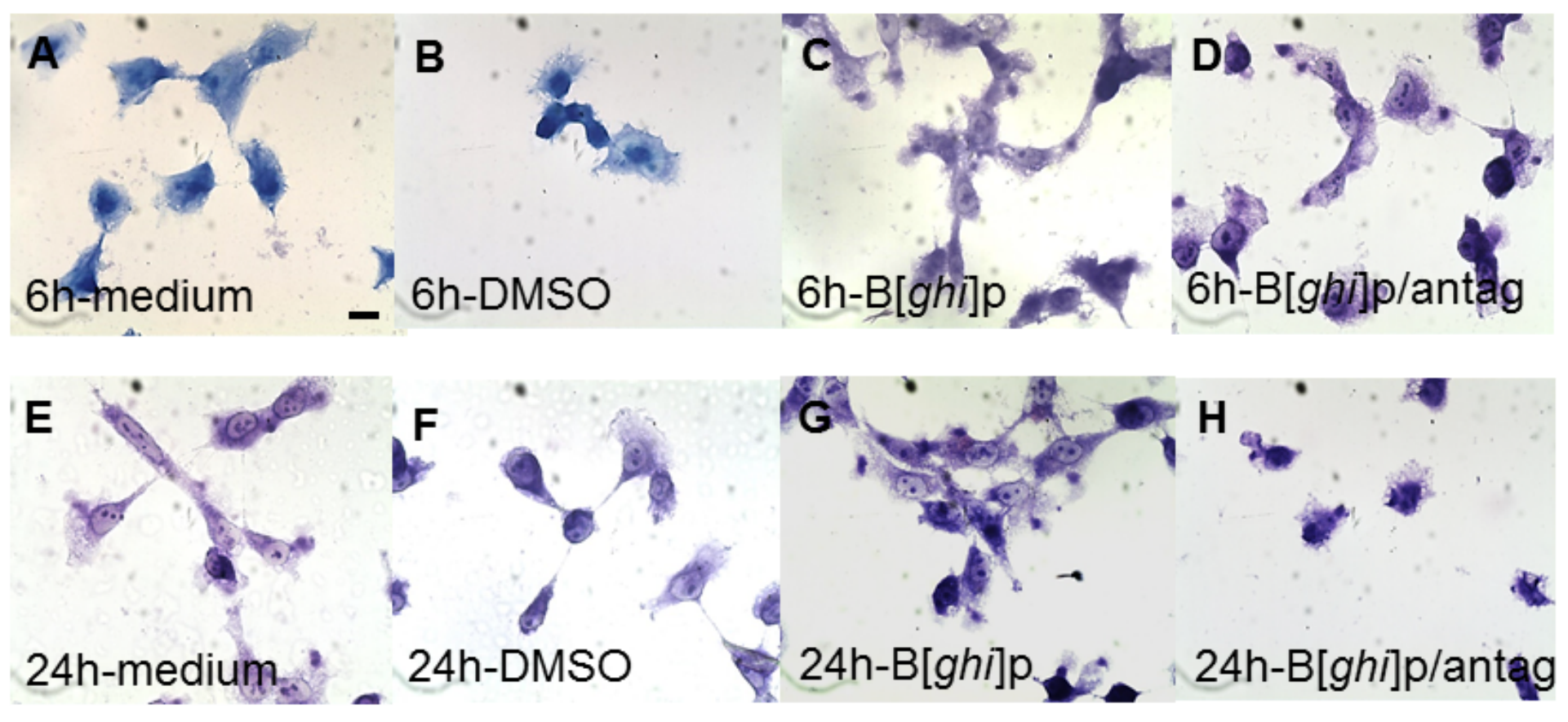

Figure 3 
Morphological changes in NL-20 cells. A. Cells growing in medium; B. Cells exposed to: DMSO; C. B[ghi]p; and D. B[ghi]p + CH-223191 (antag), by 6 hours. D. Cells growing in medium; E. Cells exposed to: DMSO; F. B[ghi]p; and G. B[ghi]p + CH-223191 (antag), by 24 hours. Microscopy of bright field. Giemsa staining. The black bar of scale is equivalent to $10 \mu \mathrm{m}$

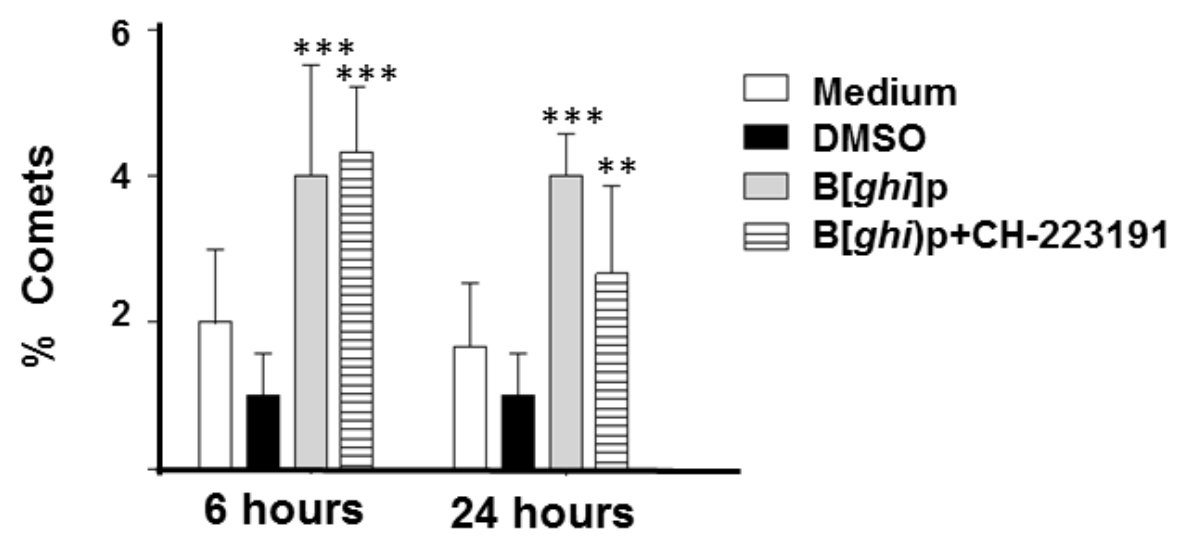

A COMETS

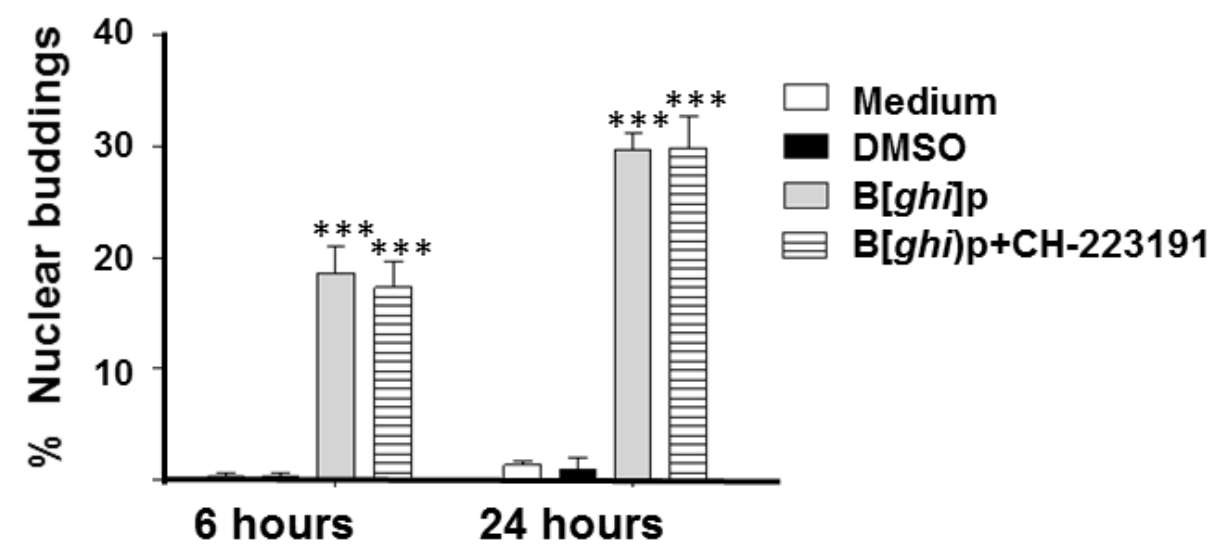

B BUDDINGS

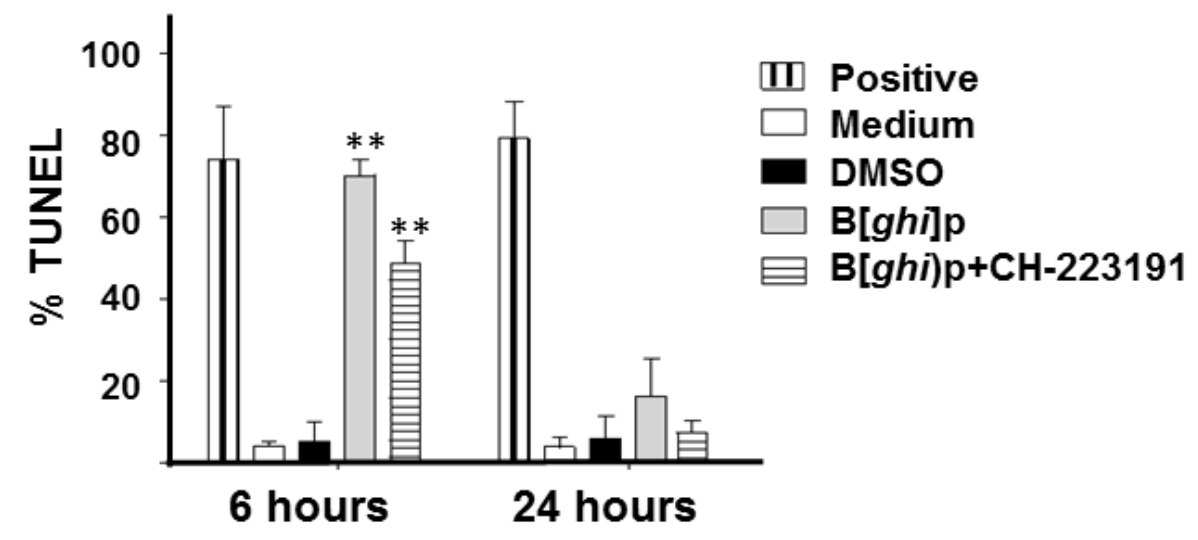

C TUNEL

Figure 4 
Genotoxic effects of B[ghi]p on NL-20 cells. A. Nucleus with comets in cells growing in medium (white bars), DMSO (black bars), B[ghi]p, (grey bars), B[ghi]p + CH-223191 (dashed bars) by 6 hours and 24 hours. Each bar shows the mean + standard error. The results are from three independent experiments. $\star \star \star ~ p<0.001, * \star p<0.01$. B. Nuclear buddings in NL-20 cells growing in medium (white bars), DMSO (black bars), $\mathrm{B}$ [ghi]p (grey bars), B[ghi]p $+\mathrm{CH}-223191$ (dashed bars) by 6 hours and 24 hours. Each bar shows the mean + standard error. The results are from three independent experiments. $* \star * p<0.001$. C. DNA fragmentation in NL-20 cells revealed by TUNEL staining. Cells exposed to $10 \mathrm{U} / \mathrm{mL}$ of DNasa I (vertical dashed bars/positive control), cells growing in medium (white bars), DMSO (black bars), B[ghi]p (grey bars), $\mathrm{B}$ [ghi]p $+\mathrm{CH}-223191$ (horizontal dashed bars) by 6 hours and 24 hours. Each bar shows the mean + standard error. The results are from three independent experiments. ${ }^{* *} p<0.01$. 